\title{
Developing an improved soil moisture dataset by blending passive and active microwave satellite-based retrievals
}

\author{
Y. Y. Liu ${ }^{1,2,4}$, R. M. Parinussa ${ }^{2}$, W. A. Dorigo ${ }^{3}$, R. A. M. De Jeu ${ }^{2}$, W. Wagner ${ }^{3}$, A. I. J. M. van Dijk ${ }^{4}$, M. F. McCabe ${ }^{1}$, \\ and J. P. Evans ${ }^{5}$ \\ ${ }^{1}$ School of Civil and Environmental Engineering, University of New South Wales, Sydney, Australia \\ ${ }^{2}$ Department of Hydrology and Geo-Environmental Sciences, Faculty of Earth and Life Sciences, \\ Vrije Universiteit Amsterdam, Amsterdam, The Netherlands \\ ${ }^{3}$ Institute for Photogrammetry and Remote Sensing, Vienna University of Technology, Vienna, Austria \\ ${ }^{4}$ CSIRO Land and Water, Black Mountain Laboratories, Canberra, Australia \\ ${ }^{5}$ Climate Change Research Centre, University of New South Wales, Sydney, Australia
}

Received: 2 August 2010 - Published in Hydrol. Earth Syst. Sci. Discuss.: 2 September 2010

Revised: 18 January 2011 - Accepted: 25 January 2011 - Published: 1 February 2011

\begin{abstract}
Combining information derived from satellitebased passive and active microwave sensors has the potential to offer improved estimates of surface soil moisture at global scale. We develop and evaluate a methodology that takes advantage of the retrieval characteristics of passive (AMSR-E) and active (ASCAT) microwave satellite estimates to produce an improved soil moisture product. First, volumetric soil water content $\left(\mathrm{m}^{3} \mathrm{~m}^{-3}\right)$ from AMSR-E and degree of saturation (\%) from ASCAT are rescaled against a reference land surface model data set using a cumulative distribution function matching approach. While this imposes any bias of the reference on the rescaled satellite products, it adjusts them to the same range and preserves the dynamics of original satellite-based products. Comparison with in situ measurements demonstrates that where the correlation coefficient between rescaled AMSR-E and ASCAT is greater than 0.65 ("transitional regions"), merging the different satellite products increases the number of observations while minimally changing the accuracy of soil moisture retrievals. These transitional regions also delineate the boundary between sparsely and moderately vegetated regions where rescaled AMSR-E and ASCAT, respectively, are used for the merged product. Therefore the merged product carries the advantages of better spatial coverage overall and increased number of observations, particularly for the transitional regions. The combination method developed has the potential to be applied
\end{abstract}

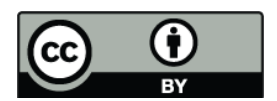

Correspondence to: Y. Y. Liu (yi.y.liu@csiro.au) to existing microwave satellites as well as to new missions. Accordingly, a long-term global soil moisture dataset can be developed and extended, enhancing basic understanding of the role of soil moisture in the water, energy and carbon cycles.

\section{Introduction}

Passive and active microwave satellites have been shown to provide useful retrievals of near-surface soil moisture variations at regional and global scales (Wagner et al., 2003; Wen et al., 2003; Njoku et al., 2003; Owe et al., 2008; Gao et al., 2006; McCabe et al., 2005). They can penetrate cloud cover and are sensitive to soil water. A series of operational satellite-based passive microwave sensors have been available since 1978, including the Scanning Multichannel Microwave Radiometer (SMMR) (1978-1987), the Special Sensor Microwave Imager (SSM/I) of the Defense Meteorological Satellite Program (since 1987), the microwave imager from the Tropical Rainfall Measuring Mission (TRMM) (since 1997), and more recently the Advanced Microwave Scanning Radiometer - Earth observing system (AMSR-E) onboard the Aqua satellite (since 2002). In terms of active microwave sensors, the European Remote Sensing (ERS-1) scatterometer began its operation from 1992, ERS-2 started collecting data from March 1996, and the Advanced Scatterometer (ASCAT) onboard the Meteorological Operational satellite programme (MetOp) was launched in October 2006.

Published by Copernicus Publications on behalf of the European Geosciences Union. 
The Soil Moisture and Ocean Salinity (SMOS) satellite launched in November 2009 carries the low frequency Lband sensor. While currently at the calibration stage, it is expected to continue the developing record of globally retrieved soil moisture data. In the coming years, numerous new satellite missions with microwave instruments are scheduled for launch (e.g., Soil Moisture Active Passive (SMAP), Aquarius, Deformation, Ecosystem Structure and Dynamics of Ice (DESDynI), and the Argentine Microwaves Observation Satellite (SAOCOM)). These are expected to bring soil moisture retrievals with further enhanced accuracy.

Various retrieval algorithms have been developed to estimate soil moisture from microwave observations (e.g., Owe et al., 2008; Njoku et al., 2003; Jackson, 1993; Wagner et al., 1999). Here we consider soil moisture products derived from two algorithms, one using passive microwave and the other active microwave observations. The algorithm developed by VU University Amsterdam in collaboration with the National Aeronautics and Space Administration (VUA-NASA) can be used for all bands in the passive microwave domain (Owe et al., 2008), allowing data collected by different satellites to be combined. The change detection algorithm developed by Vienna University of Technology (TU-Wien) has been applied on ERS-1/2 and ASCAT (Wagner et al., 1999; Bartalis et al., 2007), and provides a global satellite-based active microwave soil moisture product starting 1992.

A number of previous studies (Vischel et al., 2008; Brocca et al., 2010; Albergel et al., 2009; Gruhier et al., 2010; Rüdiger et al., 2009; Draper et al., 2009; Wagner et al., 2007) evaluated these passive and active microwave soil moisture products against in situ measurements and found that VUA-NASA passive microwave product performs better over sparsely vegetated regions, whereas the TU-Wien active microwave product shows better agreement for regions of moderate vegetation density. Over the sparsely to moderately vegetated regions, both products have similar performances. Scipal et al. (2008) and Dorigo et al. (2010) applied the triple collocation approach with VUA-NASA passive microwave, TU-Wien active microwave and model simulated soil moisture products to estimate the relative error of each product at global scale. These three products are derived from different approaches and can be considered as having independent error characteristics, the key requirement for this approach. The results confirmed that the errors of VUA-NASA passive microwave are smaller than those of the TU-Wien active microwave product for sparsely vegetated regions and larger over moderately vegetated regions. Their errors are comparable over the regions with low to moderate vegetation density.

Theoretically, passive and active microwave instruments with similar frequencies should give similar response over the same region regardless of vegetation density. The primary reason for different performances between VUANASA and TU-Wien soil moisture products lies in different ways that they account for vegetation influence on the signal. Empirical evidence suggests that the TU-Wien soil moisture performs reasonably well over regions with apparent seasonal vegetation variations (e.g., south France, Spain and southern Great Plains, see Rüdiger et al., 2009; Wagner et al., 2007; Crow et al., 2010). The VUA-NASA algorithm uses a radiative transfer model to extract soil moisture and vegetation density simultaneously. Within this algorithm, the vegetation is considered to behave like a one-layered semitransparent medium (Owe et al., 2008). With increasing vegetation density, the accuracy of soil moisture would be expected to decrease, as is confirmed by empirical evidence (e.g., Gruhier et al., 2010; Draper et al., 2009; De Jeu et al., 2008).

There may be value in developing an approach that combines both passive and active microwave soil moisture products over these varying vegetation types to develop an improved global satellite-based soil moisture product. The potential of combining passive and active microwave soil moisture was also noted by Njoku et al. (2002), Piles et al. (2009) and Das et al. (2010). Their studies were conducted using airborne data collected at small scales and short time periods at the microwave measurement level, whereas our study are conducted using multiple established satellite-based datasets at global scale and for a long time period at the soil moisture products level.

It is noted that apart from satellite observation, soil moisture can also be simulated using models (e.g., Rodell et al., 2004), based on an understanding of (simplified) physical processes (e.g., Dai et al., 2003) and observed meteorology. Data assimilation is an approach to incorporate remotely sensed soil moisture into model simulations to improve soil moisture estimates, but the final product remains primarily a modeled product. It is not clear whether the final product retains key characteristics (e.g., inter-annual variations and long term trends) detected by remotely sensed soil moisture. In any case, data assimilation is beyond the scope of this study. The objective of our study is to generate a satellitebased long term global soil moisture product by combining TU-Wien active and VUA-NASA passive microwave products.

There are some challenges. First, no single satellite covers the entire period. Differences in sensor specifications (e.g., different microwave frequencies and resolutions) prevent merging soil moisture estimates from different instruments directly. Second, the currently available VUA-NASA passive and TU-Wien active microwave products represent different quantities, that is, volumetric soil moisture and degree of saturation, respectively. Third, the accuracy of passive or active microwave products varies as a function of vegetation cover, making the selection of the better retrieval a nontrivial task, particularly where both products have comparable performances.

As a first step towards a long term global soil moisture dataset, we developed a methodology that can address the latter two challenges. That is, to adjust two products that, respectively, represent volumetric soil moisture and degree of 
saturation to the same range, and to delineate regions over which passive, active microwave products or combination of both are used in the final product. More details about VUANASA and TU-Wien products are described in Sect. 2, as well as model simulated and in situ measured soil moisture that were used. The Sect. 3 is the primary part of this methodology paper, demonstrating how both microwave soil moisture products are adjusted to the same range and then merged for an improved product. In addition, the differences and similarities between original products and the merged product are displayed. The last section summarizes the methodology and puts forward suggestions for future research.

\section{Data sources}

\subsection{AMSR-E (VUA-NASA product)}

The AMSR-E sensor onboard NASA Aqua satellite has provided passive microwave measurements at $6.9 \mathrm{GHz}$ (C-band) and five higher frequencies (including $36.5 \mathrm{GHz} \mathrm{Ka}$-band) since May 2002, with daily ascending (13:30 equatorial local crossing time) and descending (01:30 equatorial local crossing time) overpasses, over a swath width of $1445 \mathrm{~km}$.

The VUA-NASA algorithm uses the Land Parameter Retrieval Model (LPRM), requiring horizontal $(\mathrm{H})$ and vertical $(\mathrm{V})$ polarization C-band brightness temperatures $\left(T_{\mathrm{b}}\right)$, and $\mathrm{V}$ polarization Ka-band $T_{\mathrm{b}}$ from which soil surface temperature is estimated (Owe et al., 2008; Holmes et al., 2009). The vegetation optical depth (dimensionless, an indicator of vegetation density) and soil dielectric constant are derived simultaneously. The soil moisture $\left(\mathrm{m}^{3} \mathrm{~m}^{-3}\right)$ is solved from the dielectric constant using the Wang-Schmugge mixing model (Wang and Schmugge, 1980).

We used soil moisture and vegetation optical depth retrievals acquired by descending passes (01:30 equatorial local crossing time) as the minimal temperature gradients at midnight are more favourable for the retrievals (De Jeu, 2003). The C-band soil moisture represents the top few centimetres of soil, depending on the wetness. The AMSR-E products (soil moisture and vegetation optical depth) were re-sampled into $0.25^{\circ}$ (about $25 \mathrm{~km}$ ) resolution for the period from 1 January through 31 December 2007.

\subsection{ASCAT (TU-Wien product)}

The ASCAT onboard the MetOp is a real aperture radar instrument operating at $5.255 \mathrm{GHz}$ (C-band) since October 2006. Three antennas on each side of the satellite ground track measure the backscatter from the earth surface in two $550 \mathrm{~km}$ wide swaths. The three antennas on each side are oriented to broadside and $\pm 5^{\circ}$ of broadside, respectively, making sequential observations of the backscattering coefficient of each point of interest from three directions.

Soil moisture variations are adjusted between the historically lowest $(0 \%)$ and highest $(100 \%)$ values, producing a time series of relative soil moisture for the topmost centimetres of the soil. This TU-Wien change detection algorithm, originally developed for soil moisture retrievals from ERS1 and 2 (Wagner et al., 1999) was applied to ASCAT with minor adaptations (Naeimi et al., 2009).

The descending and ascending equatorial crossing time of ASCAT are respectively 09:30 and 21:30. To allow comparison with AMSR-E descending (01:30) product, the morning swaths and the evening swaths of the day before were averaged. ASCAT soil moisture was also re-sampled into $0.25^{\circ}$ resolution for the period from 1 January through 31 December 2007.

\subsection{Land surface model product}

Noah is a land surface model that forms a component of the Global Land Data Assimilation System (GLDAS). The Noah model product with 3 -h time interval and $0.25^{\circ}$ resolution is available for 2000 onwards (ftp://agdisc.gsfc.nasa. gov/data/s4pa/). The model was forced by combination of NOAA/GDAS atmospheric analysis fields, spatially and temporally disaggregated NOAA Climate Prediction Center Merged Analysis of Precipitation (CMAP) fields, and observation based downward shortwave and longwave radiation fields derived using the method of the Air Force Weather Agency's Agricultural Meteorological system (see Rodell et al., 2004 for further details).

Noah model uses a four-layered soil description with a 10$\mathrm{cm}$ thick top layer and takes into account the fractions of sand and clay. Soil moisture dynamics of the top layer are governed by infiltration, surface and sub-surface runoff, gradient diffusion, gravity and evapotranspiration.

\subsection{In situ measurements}

In situ soil moisture measurements used for comparison with the estimates from AMSR-E, ASCAT and Noah, include observations from the:

- OZNET network in south-east Australia (Young et al., 2008; Rüdiger et al., 2007);

- REMEDHUS network in central Spain (Martínez-Fernández and Ceballos, 2005);

- SMOSMANIA network in southern France (Albergel et al., 2008; Calvet et al., 2007); and

- CNR-IRPI network in Italy

(Brocca et al., 2008, 2009).

Data were downloaded from the International Soil Moisture Network website (Dorigo et al., 2011). The shallowest measurements represent approximately the top 5-10 cm, comparable with estimates derived from microwave observations and Noah simulations. Some characteristics of these different networks are listed in Table 1. Predominant land cover 
Table 1. Comparison of major characteristics of in situ soil moisture measurements used in this study. The OZNET network includes measurements within five catchments or basins. Numbers of in situ stations and grid cells covered are shown (more than one in situ station located within the same $0.25^{\circ}$ grid cell in some networks).

\begin{tabular}{llcclll}
\hline Network & Location & $\begin{array}{c}\text { in situ } \\
\text { stations }\end{array}$ & $\begin{array}{c}0.25^{\circ} \\
\text { grid cel }\end{array}$ & Climate & Major Vegetation & Soil Moisture Instruments \\
\hline REMEDHUS & central Spain & 21 & 5 & $\begin{array}{l}\text { Semi-arid } \\
\text { Mediterranean }\end{array}$ & Crops & Stevens Hydra Probe \\
\hline CNR-IRPI & central Italy & 4 & 1 & $\begin{array}{l}\text { Semi-humid } \\
\text { Mediterranean }\end{array}$ & Grass & $\begin{array}{l}\text { EnviroSCAN Sentek } \\
\text { sensor technology }\end{array}$ \\
\hline SMOSMANIA & southern France & 12 & 12 & $\begin{array}{l}\text { Atlantic (east) to } \\
\text { Mediterranean (west) }\end{array}$ & Natural fallow & Theta Probe ML2X \\
\hline OZNET & $\begin{array}{l}\text { southeastern Australia } \\
\text { (Murrumbidgee, Yanco } \\
\text { Kyeamba, Adelong, } \\
\text { and Goulburn) }\end{array}$ & 52 & 30 & $\begin{array}{l}\text { Semi-arid (inland) } \\
\text { to temperate (east) }\end{array}$ & $\begin{array}{l}\text { Pasture, Grass, } \\
\text { Crops and Oats }\end{array}$ & $\begin{array}{l}\text { Campbell Scientific } \\
615 \& 616, \\
\text { Stevens Hydra Probe }\end{array}$ \\
\hline
\end{tabular}

types around the measurement stations are grasslands, crops and pasture, which may be considered representative for low to moderate vegetation density.

\subsection{Data pre-processing}

A snow mask was developed based on ERA-Interim reanalysis data. ERA-Interim is the latest global atmospheric reanalysis produced by the European Centre for Medium-Range Weather Forecasts (ECMWF), covering the data-rich period since 1989 (Simmons et al., 2007a, b; Uppala et al., 2008; Dee and Uppala, 2009). ERA-Interim products are publicly available on the ECMWF Data Server and have $1.5^{\circ}$ resolution (http://data-portal.ecmwf.int/data/d/interim_daily/). Soil moisture and vegetation optical depth from AMSR-E and soil moisture from ASCAT were masked when the reanalysis indicated surface temperature below $0^{\circ}$ or non-zero snow depth.

The original unit of Noah soil moisture is $\mathrm{kg} \mathrm{m}^{-2}$. Considering that the top soil layer depth is $10 \mathrm{~cm}$, Noah soil moisture $\left(\mathrm{kg} \mathrm{m}^{-2}\right)$ could be converted to volumetric soil moisture $\left(\mathrm{m}^{3} \mathrm{~m}^{-3}\right)$. The 3-hourly Noah simulated soil moisture was aggregated to daily averages.

Where there were multiple in situ monitoring stations located in one $0.25^{\circ}$ grid cell, their average was taken. Time series of in situ soil moisture for grid cells with more than three (inclusive) monitoring stations are shown in Fig. 1, illustrating the spatial heterogeneity of soil moisture variations. Given this, absolute numerical agreement in satellitebased and in situ soil moisture values should not be expected. Relative patterns are similar among in situ stations, however.

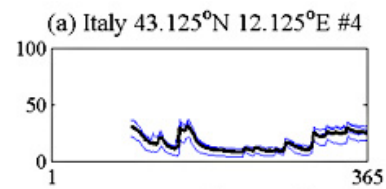

(b) Spain $41.125^{\circ} \mathrm{N} 5.375^{\circ} \mathrm{W} \# 5$

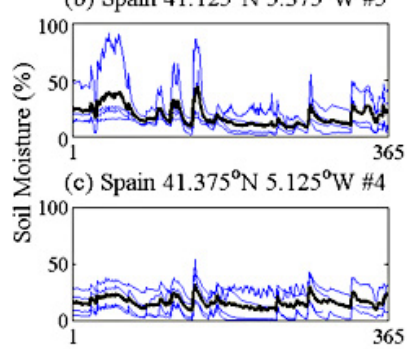

(d) Spain $41.375^{\circ} \mathrm{N} 5.375^{\circ} \mathrm{W} \# 10$

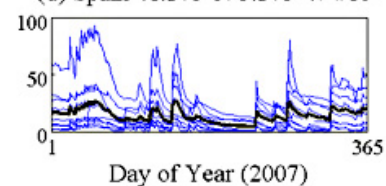

(e) Adelong $35.375^{\circ} \mathrm{S} 148.125^{\circ} \mathrm{E} \# 4$

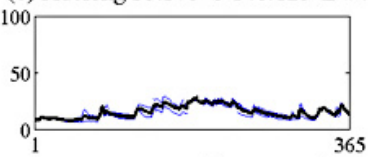

(f) Kyeamba $35.375^{\circ} \mathrm{S} 147.375^{\circ} \mathrm{E} \# 3$

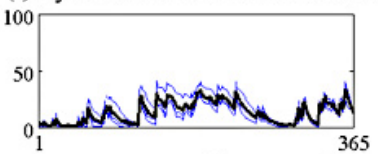

(g) Goulburn $32.175^{\circ} \mathrm{S} 150.125^{\circ} \mathrm{E} \# 5$

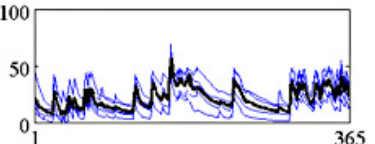

(h) Goulburn $32.175^{\circ} \mathrm{S} 150.375^{\circ} \mathrm{E} \# 4$

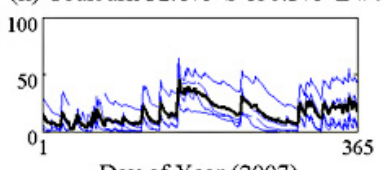

Day of Year (2007)

Fig. 1. Time series of in situ soil moisture for the eight $0.25^{\circ}$ grid cells within which more than three (inclusive) in situ stations were located. Blue represents measurement from individual in situ stations and black is the average value. Location, latitude and longitude (center of the grid cell), and number of in situ stations are listed.

\section{Methods and results}

In the merged product, the VUA-NASA and TU-Wien products were used over sparsely and moderately vegetated regions, respectively. Since passive and active products perform similarly well, both products were used over the sparsely to moderately vegetated regions (hereafter referred to as "transitional regions"). Over transitional regions, both 


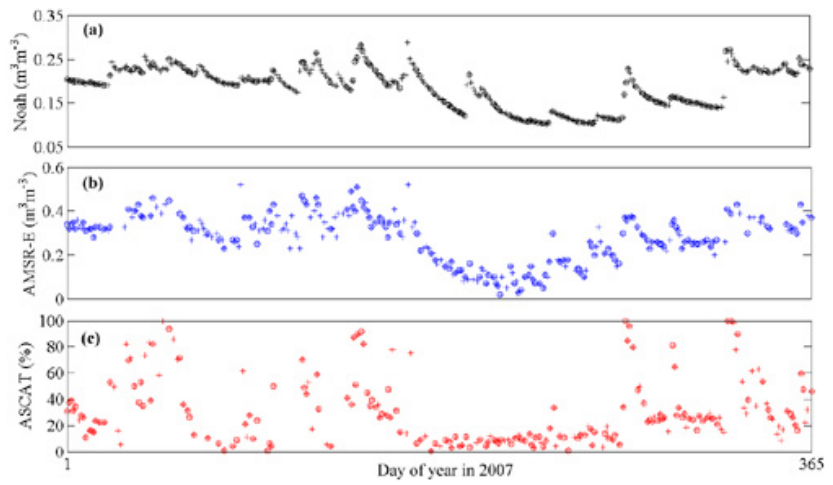

Fig. 2. Time series of soil moisture estimates from (a) Noah, (b) AMSR-E and (c) ASCAT for a grid cell (centered at $41.375^{\circ} \mathrm{N}$, $5.375^{\circ} \mathrm{W}$ ) in 2007. Circles represent days when Noah, AMSR-E and ASCAT all have valid estimates.

products are expected to be well correlated due to their similar performance. The challenge is to determine an appropriate threshold of correlation coefficient, above which an improved soil moisture product can be produced by combining both products.

To determine this threshold, we first adjusted both original products (having units of $\mathrm{m}^{3} \mathrm{~m}^{-3}$ and \% respectively) to a common range and then compare the resulting estimates to in situ measurements. Details on the method followed are presented below.

\subsection{Cumulative distribution function matching}

To combine VUA-NASA AMSR-E $\left(\mathrm{m}^{3} \mathrm{~m}^{-3}\right)$ and TU-Wien ASCAT (\%) soil moisture products, we adjust both against one reference data set. The reference data set requires global coverage with a spatial resolution and temporal interval that are comparable with the AMSR-E and ASCAT products (e.g., roughly $25 \mathrm{~km}$ resolution and daily interval); a long time record; and reasonable surface soil moisture estimates for all land cover types (e.g., representative soil layer is not deeper than $10 \mathrm{~cm}$ ).

The GLDAS-Noah model was identified as satisfying these requirements and therefore selected as the reference data set against which both satellite-based observations are rescaled. The Noah model and the VUA-NASA algorithm also use a common soil property dataset (i.e., soil porosity and fractions of clay and sand) (http://ldas.gsfc.nasa.gov/ gldas/GLDASsoils.php), based on the Food and Agriculture Organization (FAO) Soil Map of the World that was developed from a global database of over 1300 soil samples.

The cumulative distribution function (CDF) matching approach was used to adjust microwave satellite observed against the Noah simulated soil moisture. This approach was used in a number of previous studies. Reichle and Koster (2004) used it to merge satellite soil moisture observations with model data. Both Lee and Anagnostou (2004) and

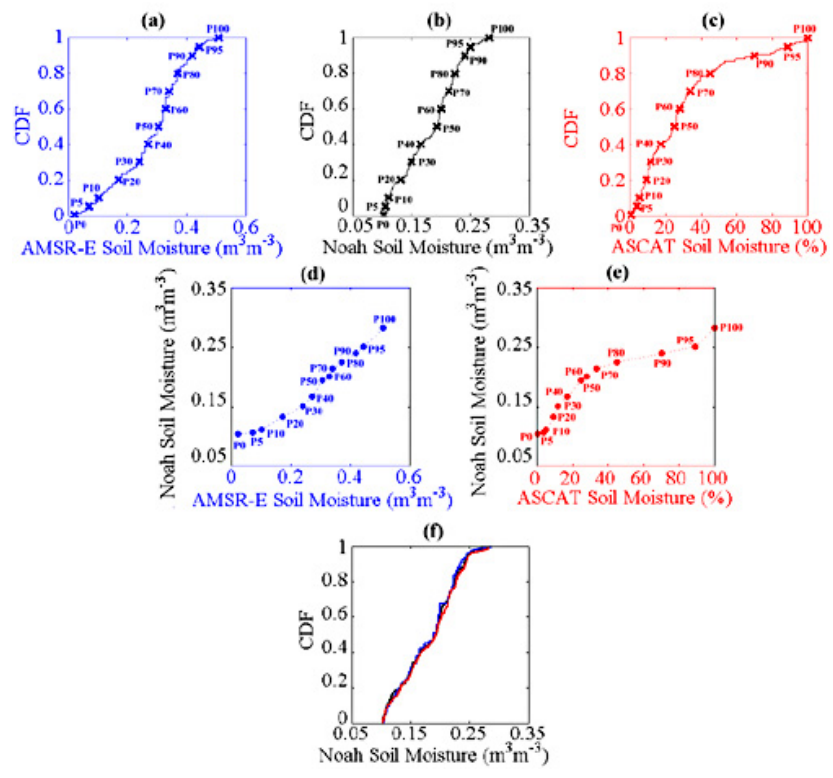

Fig. 3. Example illustrating how the cumulative distribution function (CDF) matching approach was implemented to rescale original AMSR-E and ASCAT against Noah soil moisture product in this study. (a, b, c) CDF curves of AMSR-E, Noah and ASCAT soil moisture estimates for the grid cell shown in Fig. 2. (d) Linear regression lines of AMSR-E against Noah for 12 segments. (e) Same as (d), but for ASCAT and Noah. (f) CDF curves of Noah (black), rescaled AMSR-E (blue) and rescaled ASCAT (red) soil moisture products.

Atlas et al. (1990) established reflectivity-rainfall relationships for the calibration of radar or satellite observations of precipitation, and Liu et al. (2009) produced a 29-year satellite soil and vegetation moisture data set over Australia by merging several passive microwave products using the $\mathrm{CDF}$ matching technique.

CDF matching was applied for each grid cell individually. An example grid cell (centered at $41.375^{\circ} \mathrm{N}, 5.375^{\circ} \mathrm{W}$ ) is shown in Fig. 2, where time series of soil moisture estimates from Noah, AMSR-E and ASCAT are plotted. Soil moisture values from days when Noah, AMSR-E and ASCAT are all available are marked with circles. It is expected that the CDF curves of these circled soil moisture values from different products are more directly comparable than those of all available values. The $\mathrm{CDF}$ curves of these circled values are shown in Fig. 3a, b and c. A piece-wise linear CDF matching approach was applied: dividing the CDF curve into several segments, performing linear regression analysis for each segment, and finally using the linear equations (slope and intercept) to rescale data falling into different segments.

We used the $0,5,10,20,30,40,50,60,70,80,90,95$ and 100 percentiles of the CDF curves to define $12 \mathrm{seg}$ ments (see Fig. 3a-c). The 13 percentile values from the AMSR-E and ASCAT CDF curves are plotted against those of Noah (Fig. 3d and e) and the scaling linear equations (e.g., 
(a)

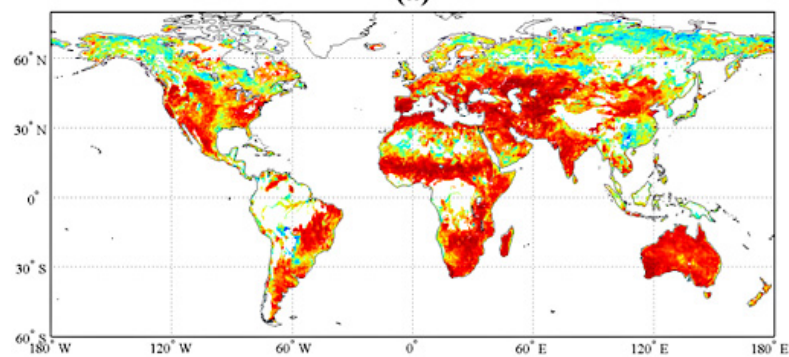

(b)

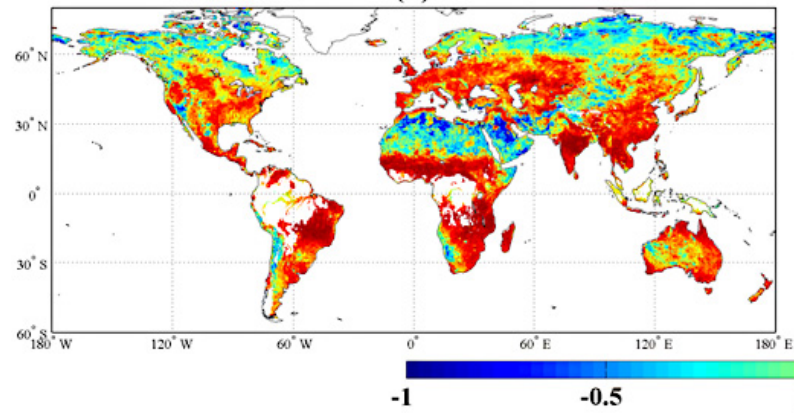

(c)

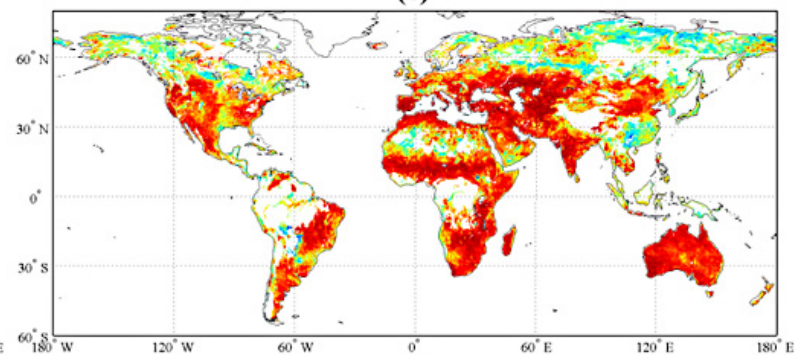

(d)

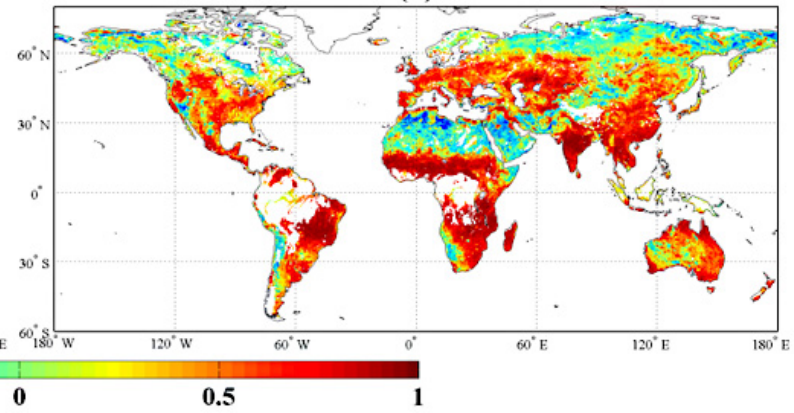

Fig. 4. Correlation coefficients $(R)$ between Noah and (a) original AMSR-E, (b) original ASCAT, (c) rescaled AMSR-E and (d) rescaled ASCAT.

slope and intercept) for each segment are obtained. Next, AMSR-E and ASCAT data falling into different segments were rescaled against Noah data. The CDF curves of original AMSR-E and ASCAT values (Fig. 3a and c) obtained after rescaling are displayed in Fig. 3f. As demonstrated, the piece-wise linear CDF matching approach well adjusts CDF curves of AMSR-E and ASCAT to that of Noah. The AMSRE and ASCAT values outside of the range of CDF curves can also be properly rescaled, using the linear equation of the closest value.

The impacts of CDF matching and Noah simulated products on the AMSR-E and ASCAT soil moisture products were examined. That is, the correlation coefficients $(R)$ between Noah and original/rescaled satellite-based products at global scale were compared (Fig. 4), together with the root mean square error (RMSE) between Noah and original/rescaled AMSR-E product (Fig. 5). For the grid cells where only one satellite product is available, the CDF matching is done using only that satellite product. $R$ and RMSE were only calculated for grid cells where AMSR-E or ASCAT and Noah have more than 20 common values. Over extremely dry regions (e.g., Sahara desert), AMSR-E has fewer soil moisture retrievals, possibly due to the constant value of surface roughness used in the VUA-NASA algorithm (Schneeberger et al., 2004; Escorihuela et al., 2007; De Jeu et al., 2009; Liu et al., 2010).

The results indicate that the rescaling process does not change the variations of original satellite-based products (compare Fig. 4a and c; Fig. 4b and d), but imposes the value range of Noah (see Fig. 5). In most applications, it

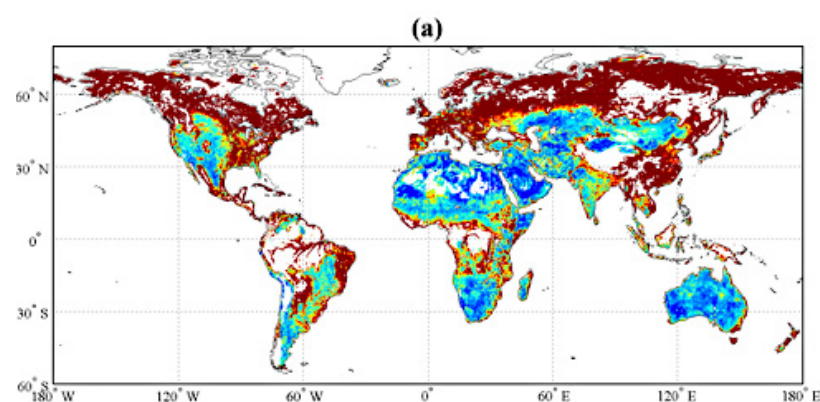

(b)

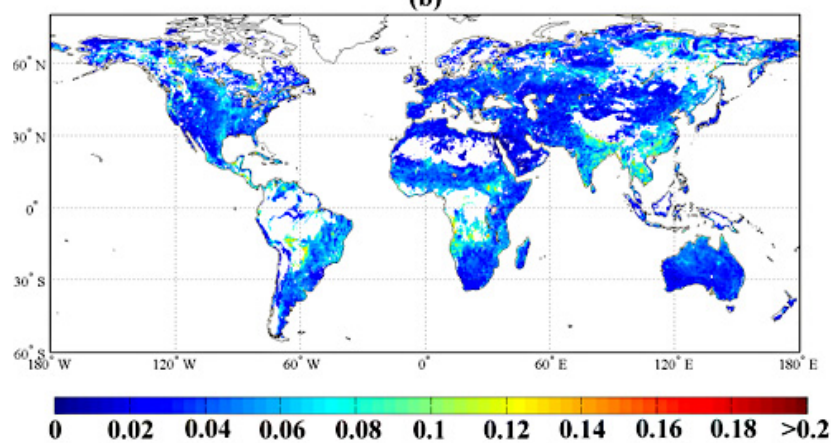

Fig. 5. The root mean square error (RMSE) between Noah and (a) original and (b) rescaled AMSR-E soil moisture estimates (Unit: $\left.\mathrm{m}^{3} \mathrm{~m}^{-3}\right)$.

is more important that the relative dynamics of soil moisture are reproduced rather than their absolute values (Brocca et al., 2010). Therefore the appropriate indicator to compare data would be the correlation coefficient $(R)$ instead of the 
(a)

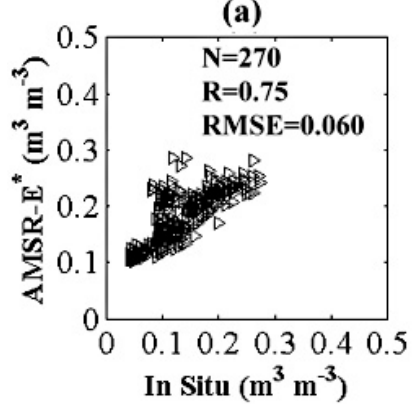

(c)
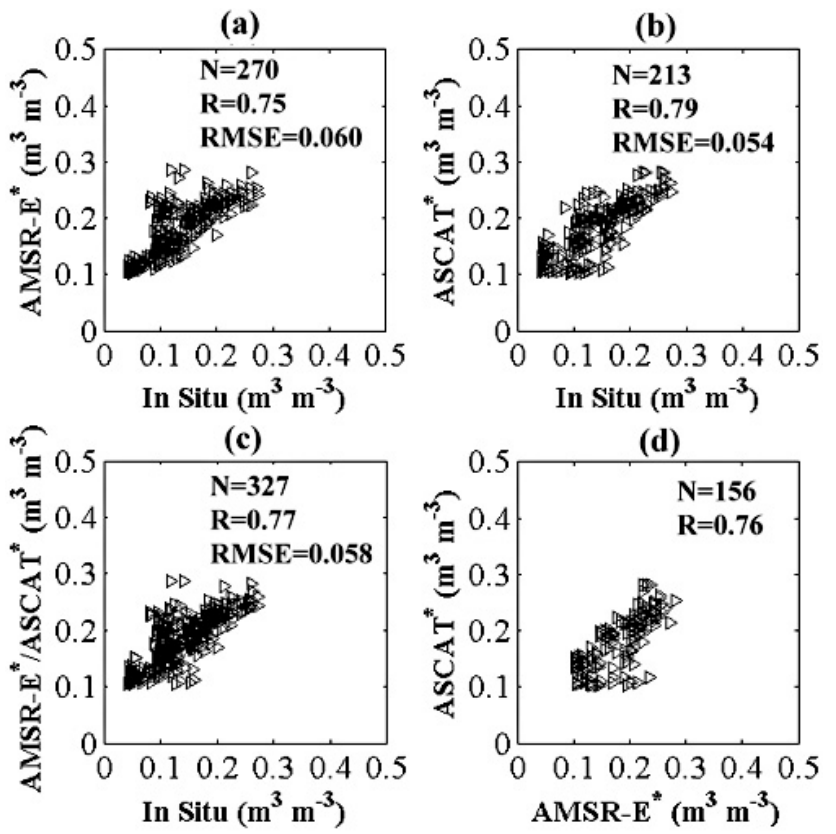

(d)

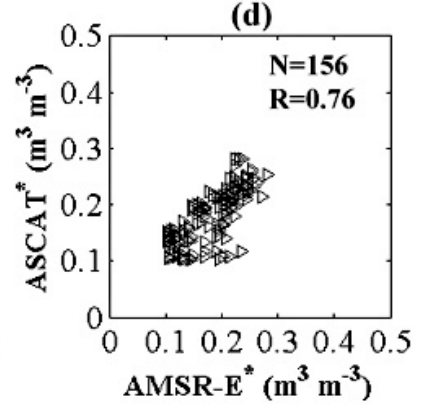

Fig. 6. Comparisons of in situ and rescaled/merged satellite-based soil moisture were conducted. The grid cell is the same as Fig. 2. Relationships between in situ and (a) rescaled AMSR-E (AMSRE*), (b) ASCAT (ASCAT*) and (c) merged AMSR-E* and ASCAT* (AMSR-E*/ASCAT*). (d) Relationship between AMSR-E* and ASCAT*.

RMSE. The CDF matching approach does not change relative patterns in the AMSR-E and ASCAT products.

\subsection{Comparison with in situ measurements}

In this section, we compare in situ measurements with the rescaled and merged satellite-based estimates to decide an appropriate threshold for the combination of both microwave soil moisture products. Figure 6 shows that combination of both satellite-based products can improve the number of observations. All in situ measurements are compared with AMSR-E* (hereafter * refers to rescaled values) and AS-

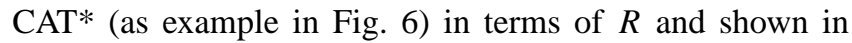
Fig. 7. At least one satellite product agrees reasonably well $(R>0.5)$ with in situ measurements for all grid cells. When both satellite products are highly correlated, their correlation with in situ data is similar (Fig. 7b). When $R$ between AMSR-E* and ASCAT $^{*}$ is greater than 0.65 , the difference between their individual $R$ with in situ measurements is smaller than 0.1. A high correlation coefficient between two satellite-based products does not directly prove that both are highly correlated with in situ data, but the fact that two fully independent datasets capture very similar temporal variations provides more confidence in both. In addition, we plot the $R$ between the merged product and in situ data (cf. Fig. 6c) with their individual $R$ with in situ data before merging (cf. Fig. 6 a and $\mathrm{b}$ ) in Fig. 8. In general, $R$ values between the merged (a)

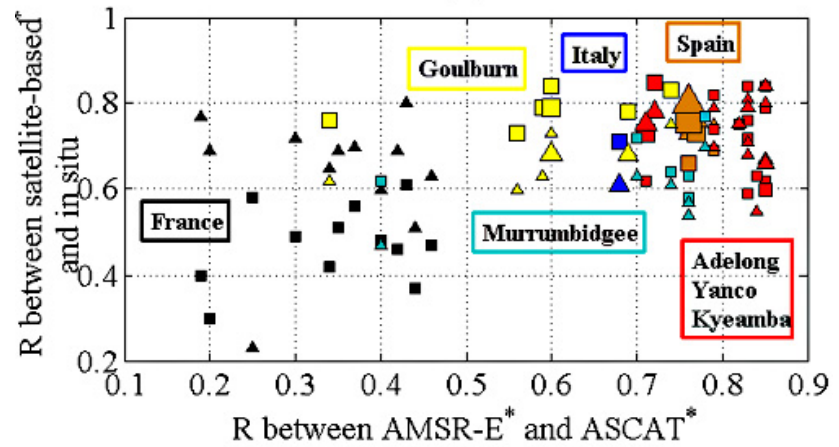

(b)

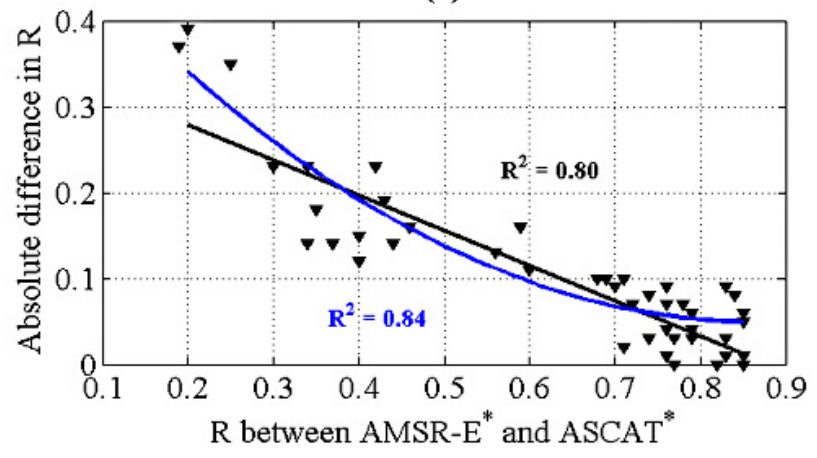

Fig. 7. (a) Plot of $R$ between AMSR-E* and ASCAT* (horizontal axis) against their individual correlation coefficient with in situ measurement (vertical axis). Different catchments or basins are marked with different colors. Triangle and square symbols, respectively, represent $R$ between in situ and ASCAT* and AMSR$E^{*}$ soil moisture. The larger the symbol, the more in situ stations located within one $0.25^{\circ}$ grid cell. (b) Plot of $R$ between AMSR$\mathrm{E}^{*}$ and $\mathrm{ASCAT}^{*}$ (horizontal axis) against the absolute difference between their individual correlation coefficient with in situ measurement (vertical axis). First-order and second-order polynomial regression lines are also shown.

product and in situ data are intermediate between their individual $R$ with in situ data. However, for cases where the two products are well correlated (inset in Fig. 8), merging them frequently leads to higher $R$ values as well as an increased number of observations.

Given these results, we conclude that merging both products increase the number of observations while minimally degrading or improving the accuracy of soil moisture estimates, when $R$ between AMSR-E* and ASCAT* is higher than 0.65. Therefore the threshold of 0.65 was chosen; AMSR-E* and ASCAT* were combined where their correlation coefficient was greater than 0.65 .

\subsection{Spatial coverage}

The correlation analysis between AMSR-E* and ASCAT* soil moisture products was carried out globally to delineate regions with a correlation coefficient $(R)$ above 0.65 , i.e., transitional regions (Fig. 9). The AMSR-E vegetation optical 


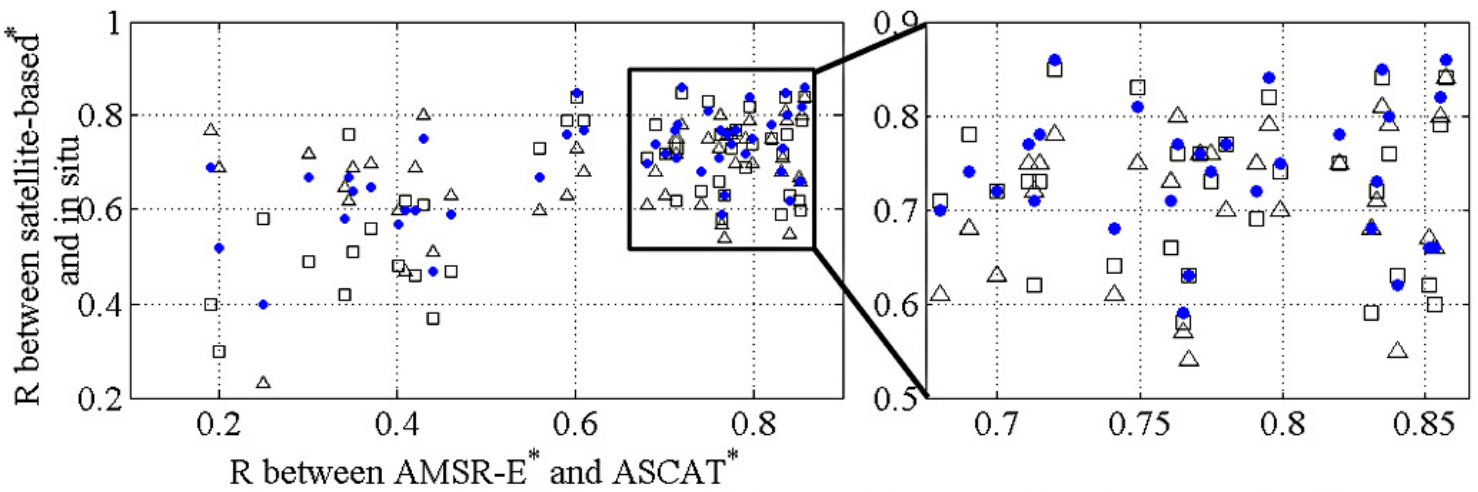

$\square \mathrm{R}\left(\mathrm{AMSR}-\mathrm{E}^{*} /\right.$ in situ $) \quad \triangle \mathrm{R}\left(\mathrm{ASCAT}^{*} /\right.$ in situ $) \quad \bullet \mathrm{R}($ Merged/in situ $)$

Fig. 8. Relationships between correlation coefficients $(R)$ between AMSR-E* (square), ASCAT* (triangle), and AMSR-E*/ASCAT* (i.e., merged product) (blue closed circles) with in situ observations, respectively.

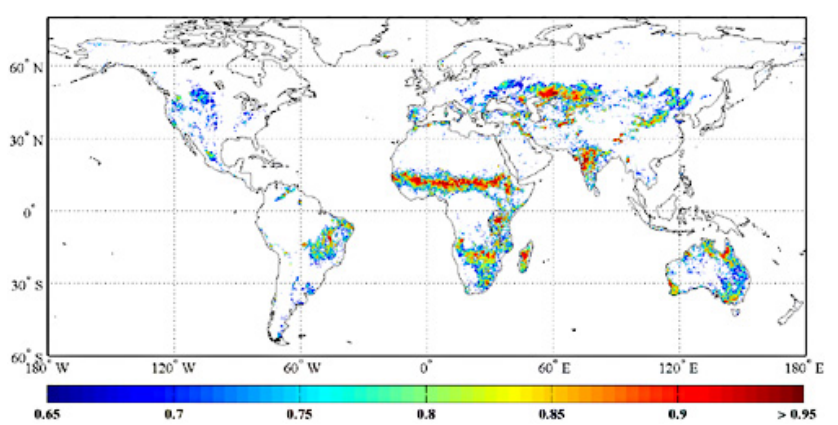

Fig. 9. Regions with high correlation coefficient $(R>0.65)$ between rescaled AMSR-E and rescaled ASCAT for 2007.

depth, retrieved simultaneously with AMSR-E soil moisture, is an indicator of vegetation density (Fig. 10). The average vegetation optical depth over the "transitional regions" is $0.42 \pm 0.18$. The VUA-NASA AMSR-E soil moisture product is used to cover the regions with lower vegetation density, whereas the TU-Wien ASCAT soil moisture product is used for regions with higher vegetation density. The spatial distribution of regions covered by AMSR-E, ASCAT and the merged product is shown in Fig. 11, and the average vegetation optical depth for these regions is, respectively, 0.20, 0.65 and 0.42 . This spatial distribution corresponds with the results of Dorigo et al. (2010) who used the triple collocation technique with VUA-NASA AMSR-E, TU-Wien ASCAT, and Noah soil moisture to determine areas where either AMSR-E or ASCAT had a smaller error value.

\subsection{Temporal resolution and overall performance}

The temporal coverage of the individual and merged products can be expressed as the fraction of the total number of days within the observation period. On average, this ratio is around $50 \%$ for the descending overpass of AMSR-E (Fig. 12a), that is, it takes two days to achieve the global

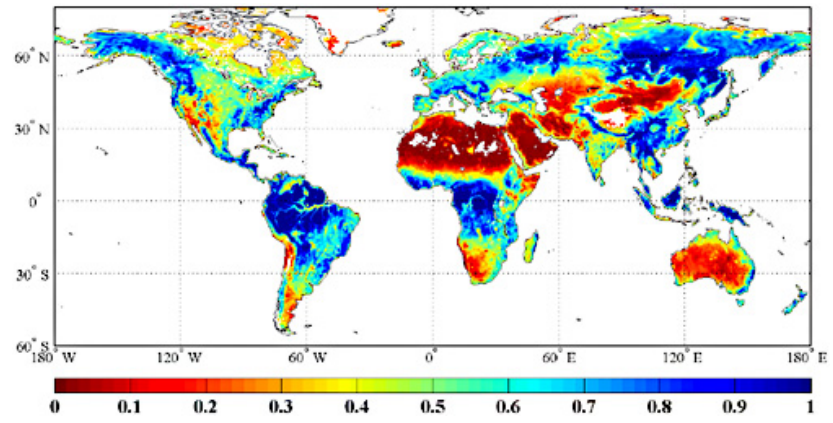

Fig. 10. Annual average of global vegetation density (via optical depth) derived from AMSR-E C-band using VUA-NASA algorithm for 2007.

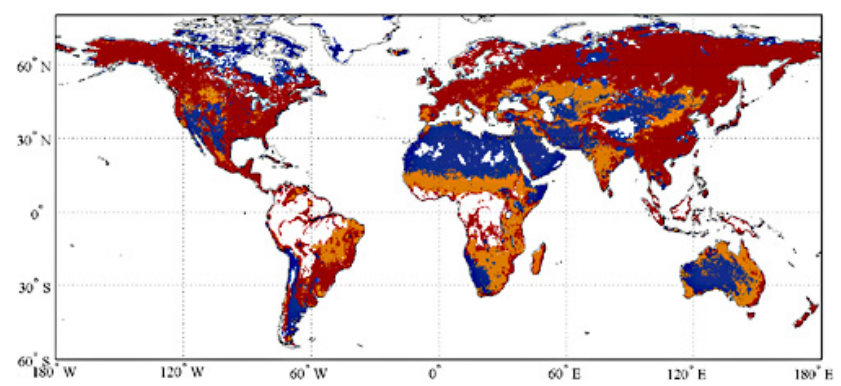

Fig. 11. Spatial coverage by AMSR-E (blue), ASCAT (red) and the merged product (orange). Tropical rain forests are masked out due to their high vegetation density.

coverage. The same frequency is achieved by the ascending and descending overpass of ASCAT combined (Fig. 12b). Over the transitional regions where AMSR-E and ASCAT products are combined, this increases data frequency to $80 \%$ (Fig. 12c). 
Table 2. Comparisons of overall performance between final merged product and individual products over different in situ soil moisture networks.

\begin{tabular}{lccc}
\hline \multirow{2}{*}{ Network } & AMSR-E* & ASCAT* & Final Product \\
\cline { 2 - 4 } & $\begin{array}{c}\text { Average } R \text { with in situ } \\
\text { (Average Temporal Ratio) }\end{array}$ & $\begin{array}{c}\text { Average } R \text { with in situ } \\
\text { (Average Temporal Ratio) }\end{array}$ & $\begin{array}{c}\text { Average } R \text { with in situ } \\
\text { (Average Temporal Ratio) }\end{array}$ \\
\hline SMOSMANIA & $0.44(69 \%)$ & $0.67(56 \%)$ & $0.67(56 \%)$ \\
Goulburn & $0.79(48 \%)$ & $0.67(51 \%)$ & $0.72(59 \%)$ \\
Italy & $0.71(60 \%)$ & $0.61(44 \%)$ & $0.70(67 \%)$ \\
Murrumbidgee & $0.66(65 \%)$ & $0.59(55 \%)$ & $0.67(79 \%)$ \\
Spain & $0.72(73 \%)$ & $0.76(55 \%)$ & $0.74(88 \%)$ \\
Yanco, Kyeamba and Adelong & $0.73(62 \%)$ & $0.73(54 \%)$ & $0.76(79 \%)$ \\
\hline
\end{tabular}

(a)

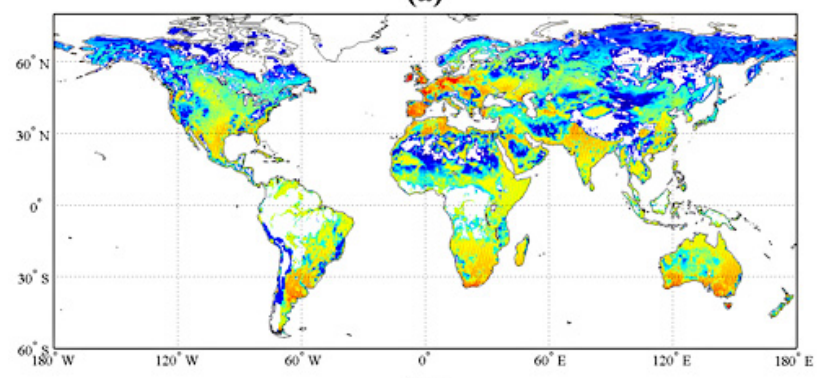

(b)

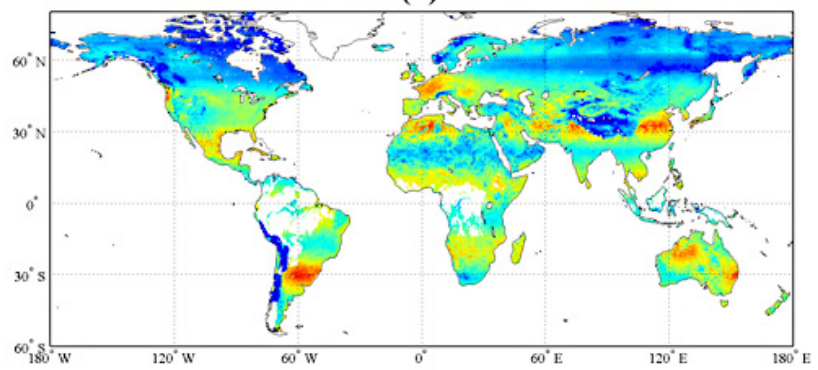

(c)

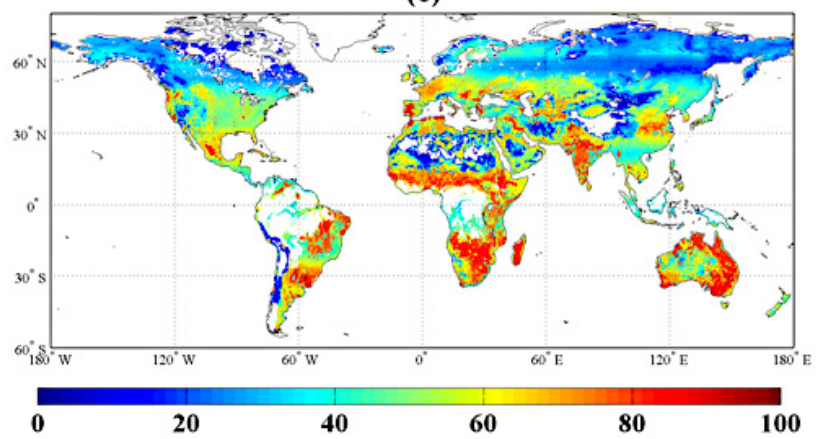

Fig. 12. Temporal coverage (i.e., fraction of days with observations) of (a) original AMSR-E, (b) original ASCAT and (c) merged product, for 2007.
Comparisons of overall performance between final merged product and individual products over different in situ networks are displayed in Table 2 . In general, the final merged product has higher number of observations while retaining good temporal patterns of individual products.

\section{Discussions and conclusions}

We developed a methodology to rescale and merge VUANASA AMSR-E and TU-Wien ASCAT C-band retrievals and produce an improved soil moisture dataset. The AMSR$\mathrm{E}$ and ASCAT products were rescaled against GLDAS-Noah simulated soil moisture using a CDF matching approach. This method does not effectively change the temporal pattern of the original products. Comparison with in situ measurements showed that provided both satellite products are well correlated $(R>0.65)$, merging can improve the temporal resolution of the data. In addition, the rescaled AMSR-E and ASCAT products were used for sparsely and moderately vegetated regions, respectively.

This approach would be applicable to both past and current microwave satellites, as well as new missions that are expected to bring higher accuracy of soil moisture retrievals. This allows for a long term global satellite-based soil moisture product to be generated and extended. The transitional regions delineated here largely correspond with the regions defined by Koster et al. (2004) where strong coupling between soil moisture and precipitation are expected. The enhancement of information by combining passive and active microwave products may help understand land surfaceatmosphere interactions and improve weather and climate prediction skill over these regions.

There are a number of opportunities for improvements. One potential issue is the effect of radio frequency interference (RFI) on the AMSR-E C-band retrievals and is observed in United States, Japan, the Middle East and elsewhere (Njoku et al., 2005). A possible solution might be the use of AMSR-E X-band instead of C-band soil moisture retrievals over these regions, although these data will correspond to 
a reduced penetration depth. When soil moisture retrievals from new missions (e.g., SMOS and SMAP) are available, blending them with existing products should provide a further improved merged product as L-band radiometer and scatterometer would bring more accurate estimates of surface soil moisture (Kerr et al., 2000; Entekhabi et al., 2010).

Spatial and temporal gaps still exist in our merged product, primarily due to satellite orbits and swath widths. This may affect the application of satellite-based soil moisture, particularly for analyses on short time basis (e.g., daily and weekly). Filling the gaps in satellite-based soil moisture products in a reasonable manner will be one of the emphases in the future analysis.

Acknowledgements. This work was undertaken as part of the European Space Agency STSE Water Cycle Multi-mission Observation Strategy (WACMOS) project (ESRIN/Contr. No. 22086/08/I-EC). We would like to thank Bob Su and Diego Fernandez-Prieto for their support. The development of the long term soil moisture dataset was also supported by the European Union (FP7) funded Framework Programme for Research and Technological Development Carbo Extreme (Contr. No. 226701). Yi Liu is funded by a University of New South Wales International Postgraduate Award (UIPA) and a scholarship from the CSIRO Water for a Healthy Country Flagship Program.

Edited by: P. van Oevelen

\section{References}

Albergel, C., Rüdiger, C., Pellarin, T., Calvet, J.-C., Fritz, N., Froissard, F., Suquia, D., Petitpa, A., Piguet, B., and Martin, E.: From near-surface to root-zone soil moisture using an exponential filter: an assessment of the method based on insitu observations and model simulations, Hydrol. Earth Syst. Sci., 12, 1323-1337, doi:10.5194/hess-12-1323-2008, 2008.

Albergel, C., Rüdiger, C., Carrer, D., Calvet, J.-C., Fritz, N., Naeimi, V., Bartalis, Z., and Hasenauer, S.: An evaluation of ASCAT surface soil moisture products with in-situ observations in Southwestern France, Hydrol. Earth Syst. Sci., 13, 115-124, doi:10.5194/hess-13-115-2009, 2009.

Atlas, D., Rosenfeld, D., and Wolff, D. B.: Climatologically Tuned Reflectivity Rain Rate Relations and Links to Area Time Integrals, J. Appl. Meteorol., 29, 1120-1135, 1990.

Bartalis, Z., Wagner, W., Naeimi, V., Hasenauer, S., Scipal, K., Bonekamp, H., Figa, J., and Anderson, C.: Initial soil moisture retrievals from the METOP-A Advanced Scatterometer (ASCAT), Geophys. Res. Lett., 34, L20401, doi:10.1029/2007GL031088, 2007.

Brocca, L., Melone, F., and Moramarco, T.: On the estimation of antecedent wetness conditions in rainfall-runoff modelling, Hydrol. Process., 22, 629-642, doi:10.1002/Hyp.6629, 2008.

Brocca, L., Melone, F., Moramarco, T., and Morbidelli, R.: Antecedent wetness conditions based on ERS scatterometer data, J. Hydrol., 364, 73-87, doi:10.1016/j.jhydrol.2008.10.007, 2009.

Brocca, L., Melone, F., Moramarco, T., Wagner, W., and Hasenauer, S.: ASCAT soil wetness index validation through in situ and modeled soil moisture data in central Italy, Remote Sens. Environ., 114, 2745-2755, doi:10.1016/j.rse.2010.06.009, 2010.

Calvet, J.-C., Fritz, N., Froissard, F., Suquia, D., Petitpa, A., and Piguet, B.: In situ soil moisture observations for the CAL/VAL of SMOS: the SMOSMANIA network, International Geoscience and Remote Sensing Symposium, IGARSS, Barcelona, Spain, 23-28 July 2007, 1196-1199, doi:10.1109/IGARSS.2007.4423019, 2007.

Crow, W. T., Wagner, W., and Naeimi, V.: The Impact of Radar Incident Angle on Soil-Moisture-Retrieval Skill, IEEE Geosci. Remote S., 7, 501-505, doi:10.1109/LGRS.2010.2040134, 2010.

Dai, Y., Zeng, X., Dickinson, R. E., Baker, I., Bonan, G. B., Bosilovich, M. G., Denning, A. S., Dirmeyer, P. A., Houser, P. R., Niu, G., Oleson, K. W., Schlosser, C. A., and Yang, Z.: The Common Land Model, B. Am. Meteorol. Soc., 84, 1013-1023, 2003.

Das, N., Entekhabi, D., and Njoku, E.: An algorithm for merging SMAP radiometer and radar data for high resolution soil moisture retrieval, IEEE T. Geosci. Remote, doi: 10.1109/TGRS.2010.2089526, in press, 2010.

De Jeu, R. A. M.: Retrieval of Land Surface Parameters Using Passive Microwave Observations, VrijeUniversiteit Amsterdam, Amsterdam, 120 pp., 2003.

De Jeu, R. A. M., Wagner, W., Holmes, T. R. H., Dolman, A. J., Giesen, N. C., and Friesen, J.: Global soil moisture patterns observed by space borne microwave radiometers and scatterometers, Surv. Geophys., 29, 399-420, doi:10.1007/s10712-0089044-0, 2008.

De Jeu, R. A. M., Holmes, T., Panciera, R., and Walker, J.: Parameterization of the Land Parameter Retrieval Model for L-Band Observations Using the NAFE'05 Data Set, IEEE Geosci. Remote S., 6, 630-634, doi:10.1109/LGRS.2009.2019607, 2009.

Dee, D. P. and Uppala, S.: Variational bias correction of satellite radiance data in the ERA-Interim reanalysis, Q. J. Roy. Meteor. Soc., 135, 1830-1841, doi:10.1002/qj.493, 2009.

Dorigo, W. A., Scipal, K., Parinussa, R. M., Liu, Y. Y., Wagner, W., De Jeu, R. A. M., and Naeimi, V.: Error characterisation of global active and passive microwave soil moisture data sets, Hydrol. Earth Syst. Sci., 14, 2605-2616, doi:10.5194/hess-142605-2010, 2010.

Dorigo, W. A., Van Oevelen, P., Wagner, W., Drusch, M., Mecklenburg, S., Robock, A., and Jackson, T.: The International Soil Moisture Network: A new data hosting facility for in-situ soil moisture data, EOS Transactions, American Geophysical Union, in review, 2011.

Draper, C. S., Walker, J. P., Steinle, P. J., De Jeu, R. A. M., and Holmes, T. R. H.: An evaluation of AMSR-E derived soil moisture over Australia, Remote Sens. Environ., 113, 703-710, doi:10.1016/j.rse.2008.11.011, 2009.

Entekhabi, D., Njoku, E. G., O’Neill, P. E., Kellogg, K. H., Crow, W. T., Edelstein, W. N., Entin, J. K., Goodman, S. D., Jackson, T. J., Johnson, J., Kimball, J., Piepmeier, J. R., Koster, R. D., Martin, N., McDonald, K. C., Moghaddam, M., Moran, S., Reichle, R., Shi, J. C., Spencer, M. W., Thurman, S. W., Leung T., van Zyl, J.: The Soil Moisture Active Passive (SMAP) Mission, Proceedings of the IEEE, 98, 704-716, doi:10.1109/JPROC.2010.2043918, 2010.

Escorihuela, M. J., Kerr, Y. H., de Rosnay, P., Wigneron, J. P., Calvet, J. C., and Lemaitre, F.: A Simple Model of the Bare Soil 
Microwave Emission at L-Band, IEEE T. Geosci. Remote, 45, 1978-1987, doi:10.1109/TGRS.2007.894935, 2007.

Gao, H., Wood, E. F., Jackson, T. J., Drusch, M., and Bindlish, R.: Using TRMM/TMI to retrieve surface soil moisture over the southern United States from 1998 to 2002, J. Hydrometeorol., 7, 23-38, 2006.

Gruhier, C., de Rosnay, P., Hasenauer, S., Holmes, T., De Jeu, R., Kerr, Y., Mougin, E., Njoku, E., Timouk, F., Wagner, W., and Zribi, M.: Soil moisture active and passive microwave products: intercomparison and evaluation over a Sahelian site, Hydrol. Earth Syst. Sci., 14, 141-156, doi:10.5194/hess-14-1412010, 2010.

Holmes, T. R. H., De Jeu, R. A. M., Owe, M., and Dolman, A. J.: Land surface temperature from Ka band $(37 \mathrm{GHz})$ passive microwave observations, J. Geophys. Res., 114, D04113, doi:10.1029/2008JD010257, 2009.

Jackson, T. J.: Measuring Surface Soil-Moisture Using Passive Microwave Remote-Sensing. III., Hydrol. Process., 7, 139-152, doi:10.1002/hyp.3360070205, 1993.

Kerr, Y., Font, J., Waldteufel, P., and Berger, M.: The Second of ESA's Opportunity Missions: The Soil Moisture and Ocean Salinity Mission - SMOS, Earth Observation Quarterly, 66, 1825, 2000.

Koster, R. D., Dirmeyer, P. A., Guo, Z. C., Bonan, G., Chan, E., Cox, P., Gordon, C. T., Kanae, S., Kowalczyk, E., Lawrence, D., Liu, P., Lu, C. H., Malyshev, S., McAvaney, B., Mitchell, K., Mocko, D., Oki, T., Oleson, K., Pitman, A., Sud, Y. C., Taylor, C. M., Verseghy, D., Vasic, R., Xue, Y. K., and Yamada, T.: Regions of strong coupling between soil moisture and precipitation, Science, 305, 1138-1140, doi:10.1126/science.1100217, 2004.

Lee, K. H. and Anagnostou, E. N.: A combined passive/active microwave remote sensing approach for surface variable retrieval using Tropical Rainfall Measuring Mission observations, Remote Sens. Environ., 92, 112-125, doi:10.1016/j.rse.2004.05.003, 2004.

Liu, Y. Y., van Dijk, A. I. J. M., De Jeu, R. A. M., and Holmes, T. R. H.: An analysis of spatiotemporal variations of soil and vegetation moisture from a 29 -year satellite-derived data set over mainland Australia, Water Resour. Res., 45, W07405, doi:10.1029/2008WR007187, 2009.

Liu, Y. Y., Evans, J. P., McCabe, M. F., De Jeu, R. A. M., van Dijk, A. I. J. M., and Su, H.: Influence of cracking clays on satellite estimated and model simulated soil moisture, Hydrol. Earth Syst. Sci., 14, 979-990, doi:10.5194/hess-14-979-2010, 2010.

Martínez-Fernández, J. and Ceballos, A.: Mean soil moisture estimation using temporal stability analysis, J. Hydrol., 312, 28-38, doi:10.1016/j.jhydrol.2005.02.007, 2005.

McCabe, M. F., Gao, H., and Wood, E. F.: Evaluation of AMSRE-derived soil moisture retrievals using ground-based and PSR airborne data during SMEX02, J. Hydrometeorol., 6, 864-877, 2005.

Naeimi, V., Bartalis, Z., and Wagner, W.: ASCAT Soil Moisture: An Assessment of the Data Quality and Consistency with the ERS Scatterometer Heritage, J. Hydrometeorol., 10, 555-563, doi:10.1175/2008JHM1051.1, 2009.

Njoku, E. G., Wilson, W. J., Yueh, S. H., Dinardo, S. J., Li, F. K., Jackson, T. J., Lakshmi, V., and Bolten, J.: Observations of soil moisture using a passive and active low-frequency microwave airborne sensor during SGP99, IEEE T. Geosci. Remote, 40,
2659-2673, doi:10.1109/Tgrs.2002.807008, 2002.

Njoku, E. G., Jackson, T. J., Lakshmi, V., Chan, T. K., and Nghiem, S. V.: Soil moisture retrieval from AMSR-E, IEEE T. Geosci. Remote, 41, 215-229, doi:10.1109/TGRS.2002.808243, 2003.

Njoku, E. G., Ashcroft, P., Chan, T. K., and Li, L.: Global survey and statistics of radio-frequency interference in AMSRE land observations, IEEE T. Geosci. Remote, 43, 938-947, doi:10.1109/Tgrs.2004.837507, 2005.

Owe, M., De Jeu, R., and Holmes, T.: Multisensor historical climatology of satellite-derived global land surface moisture, J. Geophys. Res., 113, F01002, doi:10.1029/2007JF000769, 2008.

Piles, M., Entekhabi, D., and Camps, A.: A Change Detection Algorithm for Retrieving High-Resolution Soil Moisture From SMAP Radar and Radiometer Observations, IEEE T. Geosci. Remote, 47, 4125-4131, doi:10.1109/Tgrs.2009.2022088, 2009.

Reichle, R. H. and Koster, R. D.: Bias reduction in short records of satellite soil moisture, Geophys. Res. Lett., 31, L19501, doi:10.1029/2004GL020938, 2004.

Rodell, M., Houser, P. R., Jambor, U., Gottschalck, J., Mitchell, K., Meng, C. J., Arsenault, K., Cosgrove, B., Radakovich, J., Bosilovich, M., Entin, J. K., Walker, J. P., Lohmann, D., and Toll, D.: The Global Land Data Assimilation System, B. Am. Meteorol. Soc., 85, 381-394, doi:10.1175/BAMS-85-3-381, 2004.

Rüdiger, C., Hancock, G., Hemakumara, H. M., Jacobs, B., Kalma, J. D., Martinez, C., Thyer, M., Walker, J. P., Wells, T., and Willgoose, G. R.: Goulburn River experimental catchment data set, Water Resour. Res., 43, W10403, doi:10.1029/2006wr005837, 2007.

Rüdiger, C., Calvet, J. C., Gruhier, C., Holmes, T. R. H., De Jeu, R. A. M., and Wagner, W.: An Intercomparison of ERS-Scat and AMSR-E Soil Moisture Observations with Model Simulations over France, J. Hydrometeorol., 10, 431-447, 2009.

Schneeberger, K., Schwank, M., Stamm, C., de Rosnay, P., Matzler, C. H., and Fluhler, H.: Topsoil structure influencing soil water retrieval by microwave radiometry, Vadose Zone J., 3, 1169-1179, 2004.

Scipal, K., Holmes, T., De Jeu, R., Naeimi, V., and Wagner, W.: A possible solution for the problem of estimating the error structure of global soil moisture data sets, Geophys. Res. Lett., 35, L24403, doi:10.1029/2008GL035599, 2008.

Simmons, A. J., Uppala, S. M., Dee, D. P., and Kobayashi, S.: ERAInterim: New ECMWF reanalysis products from 1989 onwards, ECMWF Newsletter, 110, 25-35, 2007a.

Simmons, A. J., Uppala, S. M., and Dee, D. P.: Update on ERAInterim, ECMWF Newsletter, 111, 5, 2007b.

Uppala, S. M., Dee, D. P., Kobayashi, S., Berrisford, P., and Simmons, A. J.: Towards a climate data assimilation system: Status update of ERA Interim, ECMWF Newsletter, 115, 12-18, 2008.

Vischel, T., Pegram, G. G. S., Sinclair, S.,Wagner,W., and Bartsch, A.: Comparison of soil moisture fields estimated by catchment modelling and remote sensing: a case study in South Africa, Hydrol. Earth Syst. Sci., 12, 751-767, 2008, http://www.hydrol-earth-syst-sci.net/12/751/2008/.

Wagner, W., Lemoine, G., and Rott, H.: A Method for Estimating Soil Moisture from ERS Scatterometer and Soil Data, Remote Sens. Environ., 70, 191-207, 1999.

Wagner, W., Scipal, K., Pathe, C., Gerten, D., Lucht, W., and Rudolf, B.: Evaluation of the agreement between the first global remotely sensed soil moisture data with model and precipitation 
data, J. Geophys. Res., 108, 4611, doi:10.1029/2003jd003663, 2003.

Wagner, W., Naeimi, V., Scipal, K., De Jeu, R., and MartínezFernández, J.: Soil moisture from operational meteorological satellites, Hydrogeol. J., 15, 121-131, doi:10.1007/s10040-0060104-6, 2007.

Wang, J. R. and Schmugge, T. J: An Empirical-Model for the Complex Dielectric Permittivity of Soils as a Function of Water Content, IEEE T. Geosci. Remote, 18, 288-295, 1980.
Wen, J., Su, Z. B., and Ma, Y. M.: Determination of land surface temperature and soil moisture from Tropical Rainfall Measuring Mission/Microwave Imager remote sensing data, J. Geophys. Res., 108, 4038, doi:10.1029/2002JD002176, 2003.

Young, R., Walker, J., Yeoh, N., Smith, A., Ellett, K., Merlin, O., and Western, A.: Soil moisture and meteorological observations from the murrumbidgee catchment, Department of Civil and Environmental Engineering, The University of Melbourne, 2008. 